Available online at GSC Online Press Directory

GSC Biological and Pharmaceutical Sciences

e-ISSN: 2581-3250, CODEN (USA): GBPSC2

Journal homepage: https://www.gsconlinepress.com/journals/gscbps

(REVIEW ARTICLE)

\title{
Monitoring of global alerts for thirteen medicines in the period 2014-2020
}

\author{
María Fernanda Rojas Salas *, Sebastián Arguedas Chacón, Raquel Arguedas Herrera, José Antonio \\ Madrigal Elizondo and Mauricio Villegas Campos \\ Pharmacy School, University of Costa Rica, San José, Costa Rica.
}

Publication history: Received on 28 September 2020; revised on 23 October 2020; accepted on 26 October 2020

Article DOI: https://doi.org/10.30574/gscbps.2020.13.2.0316

\begin{abstract}
Pharmacovigilance is based on the need to monitor and prevent possible problems caused by medications. Once national and international entities identify a problem related to medications, they issue alerts directed at health professionals, patients and the general population. In this research, national and international alerts were reviewed from 2014 to 2020, of thirteen drugs used in the treatment of common, disabling and/or fatal diseases that affect a large part of the Costa Rican population, taking alerts issued in pharmacovigilance centers databases worldwide. Health alerts show the identification of a problem and communicate the action taken by the regulatory body, which varies according to the severity of the problem. In Costa Rica, health alerts issued about drug-related effects are based on alerts issued by international regulatory bodies such as WHO and FDA, in addition to this, the Costa Rican Ministry of Health adapts the information from these alerts to the Costa Rican population. However, of the ten alerts analyzed, four were not issued in Costa Rica.
\end{abstract}

Keywords: Pharmacovigilance; Alerts; Measures; Costa Rica; Medicines

\section{Introduction}

Pharmacovigilance is based on the need to monitor and prevent possible problems caused by medications. Pharmacological therapy has greatly increased over time, which is why it is important to invest in the detection, assessment and prevention of these problems [1].

Also, pharmacovigilance may be referred to as post-marketing studies, therefore it is important to collect information regarding medications when used in population heterogeneity. It is desirable that when a drug receives the registration and permission to be marketed, it can be properly introduced into systems where its safety can be adequately monitored. For this reason, the countries have established the process of notification of adverse reactions or Pharmacovigilance Systems [2].

An adverse drug effect refers to any unwanted adverse effect that occurs at the doses used for the prevention, diagnosis or treatment of a disease, in addition, they are one of the causes of morbidity and mortality in hospitalized patients. Adverse effects are generally not discovered until the drug has been released [3], this gives great importance to pharmacovigilance, since the identification and reporting of adverse effects predict the danger of future administrations of the drug and justify prevention, personalized treatment, alteration of the dosage regimen or withdrawal of the product [4].

\footnotetext{
${ }^{*}$ Corresponding author: Fernanda Rojas Salas

Pharmacy School, University of Costa Rica, San José, Costa Rica.

Copyright (C) 2020 Author(s) retain the copyright of this article. This article is published under the terms of the Creative Commons Attribution Liscense 4.0.
} 
Medication errors correspond to those preventable events that can cause or lead to inappropriate use of medications or harm to patients. Such events may be related to professional practices, health care products, procedures or systems such as prescription, product labeling, packaging, dispensing, distribution, monitoring [5,6], they can occur at any stage of the medication use process and may or may not lead to adverse drug reactions [7].

The World Health Organization (WHO) defines counterfeit medical products as those that purposely or illegally alter their identity, composition or origin. These may not contain the specified active ingredients, incorrect active ingredients or have correct amounts of the correct ingredients, so they can become ineffective in treating diseases and even become toxic, harmful and lethal in some cases [8].

Community pharmacists are the most frequently visited health professionals, and they have the tools and knowledge necessary to make an adequate report of adverse reactions [9]. However, according to the World Health Organization's International Drug Monitoring Program, the contribution of community pharmacists in the reporting of adverse effects is generally low. There are some exceptions such as the Netherlands, where community pharmacists play a key role in adverse drug reaction reporting in their national pharmacovigilance system [10].

The pharmaceutical industry has an essential responsibility for the safety of medicines. Manufacturers are in a unique position to monitor the safety of drugs, from the beginning of drug development and subsequently throughout the life of the drug. Many pharmaceutical industries have created new and efficient monitoring systems that have helped to identify new safety signals [11].

The information obtained allows the pharmaceutical industry to calculate the incidence of adverse reactions, the balance between benefit and harm, comparisons with alternative treatments and to predict the consequences if a drug is used in special groups[12].

In the past decade, more than 65 countries had their own pharmacovigilance centers. Membership of the World Organization for Drug Monitoring is coordinated by the WHO collaborating center called the Uppsala Monitoring Center (UMC). The Uppsala Monitoring Center is responsible for managing the international database of adverse event reports received from pharmacovigilance centers [13].

National Pharmacovigilance Centers are responsible for creating and increasing public awareness of drug safety and for establishing active surveillance programs using record-linkage and prescription case surveillance systems to collect epidemiological information on adverse drug reactions [13].

In Costa Rica, the entity responsible for pharmacovigilance is the National Center for Pharmacovigilance, which is attached to the Ministry of Health. There is a manual of Good Pharmacovigilance Practices that regulates the National Pharmacovigilance System, which is the program that integrates the activities to be carried out by health institutions for the collection and processing of information related to adverse drug reactions that occur in the country [14].

The National Pharmacovigilance System is made up of the National Center for Pharmacovigilance, health professionals, the pharmaceutical industry, the National Pharmacovigilance Commission and the regulatory authorities [14].

Within the National Center for Pharmacovigilance, the National Commission for Pharmacovigilance is the advisory body, composed of health professionals with experience in the assessment of the risk-benefit of medicines [14].

In addition, the Clodomiro Picado Institute, since it markets antiophidic serums worldwide, also has an important pharmacovigilance component, since through the reporting, registration and systematic evaluation of adverse drug reactions, the well-being of patients can be improved and looked after [15].

\section{Material and methods}

A bibliographic review was carried on national and international alerts from 2014 to 2020, of thirteen drugs used in the treatment of common, disabling and/or fatal diseases that affect much of the Costa Rican population, these were: lorcaserin, vortioxetine, pregabalin, gabapentin, ondansetron, ranitidine, pioglitazone, denosumab, ivabradine, ticagrelor, saxagliptin, alogliptin and lamotrigine.

The review was carried out using the following pharmacovigilance databases: Costa Rican Ministry of Health, Costa Rican Social Security Fund (CCSS), World Health Organization (WHO), Food and Drug Administration (FDA), Uppsala 
Monitoring Center, European Medicines Agency (EMA), United Kingdom Medicines and Healthcare products Regulatory Agency (MHRA), Australian Therapeutic Goods Administration (TGA), Colombian National Institute of Food and Drug Administration (Invima), Peruvian National Drug Information Center (CenadIM), Japanese Ministry of Health, Labor, and Welfare (MHLW/PMDA), Brazilian National Health Surveillance Agency (ANVISA), Ministry of Health of the Government of Chile, Spanish Agency of Drugs and Health Products and the Association of Pharmacists of the province of Santa Fe, Argentina.

Medicines that were issued a safety alert in at least two databases were taken into account to evaluate the extent to which they were used to treat common, disabling and/or fatal diseases that affect a large part of the Costa Rican population.

The alerts include the drug, the drug-related problem, its justification and the action taken by the regulatory authorities.

\section{Results and discussion}

Table 1 Actions taken in Costa Rica and the world by alerts on medications issued by the main health authorities.

\begin{tabular}{|c|c|c|c|c|}
\hline $\begin{array}{l}\text { Active principle/ } \\
\text { commercial brand }\end{array}$ & $\begin{array}{l}\text { Issuer of the alert } \\
\text { (year of issue) }\end{array}$ & Reason of the alert & $\begin{array}{l}\text { Action taken in } \\
\text { Costa Rica } \\
\text { (year of execution) }\end{array}$ & $\begin{array}{l}\text { Actions taken at } \\
\text { international level } \\
\text { (year of execution) }\end{array}$ \\
\hline $\begin{array}{l}\text { Lorcaserin } \text { Relucit }^{\circledR} \text {, } \\
\text { Belviq }^{\circledR}, \text { Belviq XR }{ }^{\circledR} \text {, } \\
\text { Repentil }^{\circledR}, \\
\text { Obesilox }^{\circledR} \text { ) }\end{array}$ & $\begin{array}{l}\text { FDA (2020) } \\
\text { Costa Rican Ministry } \\
\text { of Health (2020) } \\
\text { ANVISA (2020) }\end{array}$ & $\begin{array}{l}\text { Increased risk of } \\
\text { cancer [16-18]. }\end{array}$ & $\begin{array}{l}\text { Costa Rican Ministry } \\
\text { of Health (2020): } \\
\text { request the } \\
\text { withdrawal of } \\
\text { lorcaserin from the } \\
\text { market [16]. }\end{array}$ & $\begin{array}{l}\text { United States } \\
(2020) \text { : request the } \\
\text { withdrawal of } \\
\text { lorcaserin from the } \\
\text { market [17]. } \\
\text { Brazil } \\
\text { marketing } \\
\text { suspension } \\
\text { Belviq }^{\circledR}[18] .\end{array}$ \\
\hline $\begin{array}{l}\text { Pregabalin (Lyrica }{ }^{\circledR} \text {, } \\
\text { Lyrica CR }{ }^{\circledR} \text { ) } \\
\text { Gabapentin } \\
\text { (Neurontin }{ }^{\circledR} \text {, } \\
\text { Gralise }^{\circledR}, \text { Horizant }^{\circledR} \text { ) }\end{array}$ & $\begin{array}{l}\text { FDA (2019) } \\
\text { MHRA (2018) }\end{array}$ & $\begin{array}{l}\text { Serious breathing } \\
\text { problems, medicinal } \\
\text { misuse, illegal } \\
\text { diversion of the } \\
\text { drugs and addiction } \\
{[19,20] .}\end{array}$ & $\begin{array}{l}\text { As of the revision } \\
\text { date, the Ministry of } \\
\text { Health of Costa Rica } \\
\text { has not issued an } \\
\text { alert in this regard. }\end{array}$ & $\begin{array}{l}\text { United States } \\
\text { (2019): new warning } \\
\text { on risk of respiratory } \\
\text { depression in the } \\
\text { safety information of } \\
\text { the drug. Request to } \\
\text { the manufacturer for } \\
\text { clinical trials on } \\
\text { potential abuse, } \\
\text { particularly with } \\
\text { opioids [19]. } \\
\text { United Kingdom } \\
\text { (2019): } \\
\text { Reclassification to } \\
\text { class C (controlled } \\
\text { drugs) [20]. }\end{array}$ \\
\hline $\begin{array}{l}\text { Ondansetron } \\
\text { (Northia }^{\circledR} \text {, } \\
\text { Modifical }^{\circledR} \text {, } \\
\text { Onsetron-Denk }^{\circledR} \text {, } \\
\text { Zofran }^{\circledR} \text { ) }\end{array}$ & $\begin{array}{l}\text { WHO (2020) } \\
\text { MHRA (2020) } \\
\text { Costa Rican Ministry } \\
\text { of Health (2019) }\end{array}$ & $\begin{array}{l}\text { Risk of orofacial } \\
\text { closure defects such } \\
\text { as cleft palate and } \\
\text { cleft lip related to } \\
\text { ondansetron use } \\
\text { during the first } 12\end{array}$ & $\begin{array}{l}\text { Costa Rican Ministry } \\
\text { of Health (2019): } \\
\text { Recommendations to } \\
\text { healthcare } \\
\text { professionals and } \\
\text { updating safety } \\
\text { information for }\end{array}$ & $\begin{array}{l}\text { WHO and United } \\
\text { Kingdom (2020): } \\
\text { Limit the use of } \\
\text { ondansetron in the } \\
\text { early weeks of } \\
\text { pregnancy to } \\
\text { medical judgment }\end{array}$ \\
\hline
\end{tabular}




\begin{tabular}{|c|c|c|c|c|}
\hline & & $\begin{array}{l}\text { weeks of pregnancy } \\
{[21-23] \text {. }}\end{array}$ & $\begin{array}{l}\text { medications } \\
\text { containing } \\
\text { ondansetron in their } \\
\text { formulations [22]. }\end{array}$ & $\begin{array}{l}\text { and to the patient's } \\
\text { previously informed } \\
\text { decision about the } \\
\text { benefits and risks to } \\
\text { her and the fetus } \\
{[21,23] \text {. }}\end{array}$ \\
\hline $\begin{array}{lr}\text { Ranitidine } & \text { (La } \\
\text { Santé } & \text { GENFAR } \\
\text { MK }^{\circledR}, & \text { GEntac } \\
\text { Sandoz }^{\circledR} & \end{array}$ & $\begin{array}{l}\text { FDA (2019) } \\
\text { TGA (2019) } \\
\text { Invima (2019) } \\
\text { Costa Rican Ministry } \\
\text { of Health (2019) }\end{array}$ & $\begin{array}{l}\text { Presence of a } \\
\text { nitrosamine known } \\
\text { as } \\
\text { nitrosodimethylami } \\
\text { ne (NDMA) in several } \\
\text { batches of the } \\
\text { ranitidine } \\
{[24] .}\end{array}$ & $\begin{array}{l}\text { Costa Rican Ministry } \\
\text { of Health (2019): } \\
\text { Recall of oral } \\
\text { medicines } \\
\text { containing ranitidine } \\
{[25] \text {. }}\end{array}$ & 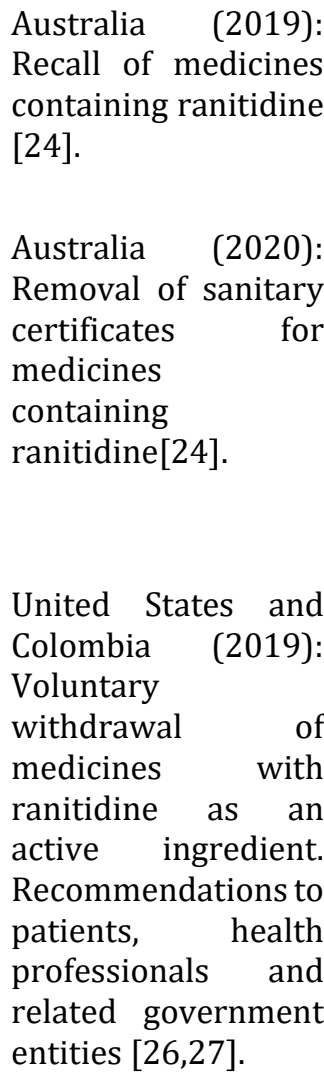 \\
\hline $\begin{array}{l}\text { Pioglitazone } \\
\text { (Piomed }^{\circledR}, \\
\text { Actoplus } \\
\text { Actoplus } \text { Met }^{\circledR}, \\
\text { Actor }{ }^{\circledR} \\
\text { Duetact }{ }^{\circledR}, \\
\text {, Oseni }{ }^{\circledR} \text { ) }\end{array}$ & $\begin{array}{l}\text { FDA (2016) } \\
\text { Costa Rican Ministry } \\
\text { of Health (2017) }\end{array}$ & $\begin{array}{l}\text { Significant increase } \\
\text { in the risk of bladder } \\
\text { cancer }[28,29] \text {. }\end{array}$ & $\begin{array}{l}\text { Costa Rican Ministry } \\
\text { of Health (2017): } \\
\text { Update of the safety } \\
\text { information for } \\
\text { medicines } \\
\text { containing } \\
\text { pioglitazone in their } \\
\text { formulations [28]. }\end{array}$ & $\begin{array}{l}\text { United States } \\
(2016) \text { : Update of } \\
\text { the safety } \\
\text { information for } \\
\text { medicines } \\
\text { containing } \\
\text { pioglitazone in their } \\
\text { formulations. In } \\
\text { active bladder } \\
\text { cancer patients this } \\
\text { active principle } \\
\text { should not be used } \\
\text { and in patients with } \\
\text { cancer history, risks } \\
\text { and benefits should } \\
\text { be considered } \\
\text { [29]. }\end{array}$ \\
\hline $\begin{array}{l}\text { Denosumab } \\
\text { (Prolia }^{\circledR}, \text { Xgeva }^{\circledR} \text { ) }\end{array}$ & $\begin{array}{l}\text { WHO (2019) } \\
\text { MHLW/PMDA } \\
(2019) \\
\text { MHRA (2018) }\end{array}$ & $\begin{array}{l}\text { Risk of } \\
\text { hypercalcemia and } \\
\text { multiple vertebral } \\
\text { fractures [30-33]. }\end{array}$ & $\begin{array}{l}\text { As of the revision } \\
\text { date, the Costa Rican } \\
\text { Ministry of Health } \\
\text { has not issued an } \\
\text { alert in this regard. }\end{array}$ & $\begin{array}{l}\text { United Kingdom } \\
(2018) \text {, WHO and } \\
\text { Japan (2019): } \\
\text { Monitor and advise } \\
\text { patients of the signs } \\
\text { and symptoms of } \\
\text { hypercalcemia after } \\
\text { discontinuing }\end{array}$ \\
\hline
\end{tabular}




\begin{tabular}{|c|c|c|c|c|}
\hline & ANVISA (2017) & & & $\begin{array}{l}\text { denosumab, do not } \\
\text { use in growing } \\
\text { patients [30-32]. } \\
\text { Brazil (2017): } \\
\text { Update of the safety } \\
\text { information for } \\
\text { medicines } \\
\text { containing } \\
\text { denosumab in their } \\
\text { formulations [33]. }\end{array}$ \\
\hline $\begin{array}{l}\text { Vortioxetine } \\
\left(\text { Brintellix }^{\circledR} \text { ) }\right. \\
\text { Ticagrelor } \\
\text { (Brilinta }^{\circledR} \text { ) }\end{array}$ & $\begin{array}{l}\text { FDA (2015-2016) } \\
\text { WHO (2015) } \\
\text { Peruvian Ministry of } \\
\text { Health (2016) } \\
\text { Ministry of Health of } \\
\text { the Government of } \\
\text { Chile (2016) } \\
\text { Association of } \\
\text { Pharmacists of the } \\
\text { province of Santa Fe, } \\
\text { Argentina (2016) }\end{array}$ & $\begin{array}{l}\text { Medication error: } \\
\text { Prescription and } \\
\text { dispensing confusion } \\
\text { due to similarity in } \\
\text { names } \\
{[34-38] .}\end{array}$ & $\begin{array}{l}\text { As of the review date, } \\
\text { the Costa Rican } \\
\text { Ministry of Health } \\
\text { has not issued an } \\
\text { alert in this regard. }\end{array}$ & $\begin{array}{l}\text { 1. United States } \\
\text { (2015): The } \\
\text { medication error is } \\
\text { disclosed by the alert } \\
\text { given by the FDA. } \\
\text { 2. United States and } \\
\text { WHO (2015-2016): } \\
\text { name change from } \\
\text { Brintellix } \\
\text { Trintellix accepted } \\
\text { [34,35]. } \\
\text { 3. Peru, Chile and } \\
\text { Argentina (2016): } \\
\text { Prescription and } \\
\text { dispensing warnings } \\
\text { issued for these } \\
\text { medications [36-38]. }\end{array}$ \\
\hline $\begin{array}{l}\text { Ivabradine } \\
\left(\text { Corlentor }{ }^{\circledR},\right. \\
\text { Procoralan }^{\circledR} \text { ) }\end{array}$ & $\begin{array}{l}\text { TGA (2014) } \\
\text { EMA (2014) } \\
\text { WHO (2015) } \\
\text { Costa Rican Ministry } \\
\text { of Health (2014) } \\
\text { MHRA (2014) } \\
\text { Spanish Agency of } \\
\text { Drugs and Health } \\
\text { Products (2014) } \\
\text { Invima (2015) }\end{array}$ & $\begin{array}{l}\text { New indications of } \\
\text { use for Ivabradine } \\
\text { following the } \\
\text { findings of the } \\
\text { SIGNIFY study [39- } \\
\text { 45]. }\end{array}$ & $\begin{array}{l}\text { Costa Rican Ministry } \\
\text { of Health (2014): } \\
\text { The alert is issued } \\
\text { with information on } \\
\text { the new indications } \\
\text { for Ivabradine's use } \\
\text { [39]. }\end{array}$ & $\begin{array}{l}\text { United } \\
\text { European } \\
\text { Australes, } \\
\text { Spain anion, Colombia, } \\
\text { Kingdom } \\
\text { 2015): issue the alert } \\
\text { with the information } \\
\text { of the new } \\
\text { indications for use } \\
\text { for Ivabradine [39- } \\
45] \text {. }\end{array}$ \\
\hline
\end{tabular}




\begin{tabular}{|c|c|c|c|c|}
\hline $\begin{array}{l}\text { Saxagliptin } \\
\left(\text { Onglyza }{ }^{\circledR} \quad \mathrm{y}\right. \\
\left.\text { Kombiglyze XR }^{\circledR}\right) \\
\text { Alogliptin (Nesina }{ }^{\circledR}, \\
\text { Kazano }^{\circledR} \text { y Oseni }{ }^{\circledR} \text { ) }\end{array}$ & $\begin{array}{l}\text { FDA (2016) } \\
\text { WHO (2016) } \\
\text { Costa Rican Ministry } \\
\text { of Health (2016) } \\
\text { ANVISA (2016) }\end{array}$ & $\begin{array}{l}\text { Increased risk of } \\
\text { heart failure, } \\
\text { especially in patients } \\
\text { with heart or kidney } \\
\text { disease [46-49]. }\end{array}$ & $\begin{array}{l}\text { Costa Rican Ministry } \\
\text { of Health (2016): } \\
\text { Update on the safety } \\
\text { of drugs containing } \\
\text { saxagliptin. } \\
\text { Recommendation to } \\
\text { health personnel to } \\
\text { consider } \\
\text { discontinuation of } \\
\text { medication if } \\
\text { patients affected } \\
\text { heart failure. Report } \\
\text { adverse effects [48]. }\end{array}$ & 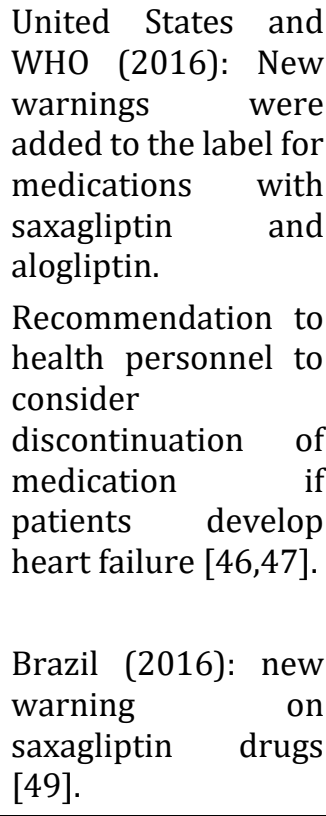 \\
\hline $\begin{array}{l}\text { Lamotrigine } \\
\left.\text { (Lamictal }^{\circledR}\right)\end{array}$ & $\begin{array}{l}\text { FDA (2018) } \\
\text { WHO (2018) } \\
\text { Invima (2018) } \\
\text { CenadIM (2018) }\end{array}$ & $\begin{array}{l}\text { Risk of } \\
\text { hemophagocytic } \\
\text { lymphohistiocytosi } \\
\text { reaction (HLH) [50- } \\
53 \text { ]. }\end{array}$ & $\begin{array}{l}\text { As of the revision } \\
\text { date, the Ministry of } \\
\text { Health of Costa Rica } \\
\text { has not issued an } \\
\text { alert in this regard. }\end{array}$ & $\begin{array}{l}\text { USA, WHO and Peru } \\
\text { (2018): Added } \\
\text { warning about HLH } \\
\text { risk on drug labels } \\
{[50,51] \text {. }} \\
\text { Colombia (2018): a } \\
\text { HLH hazard warning } \\
\text { was added to the } \\
\text { drug label and insert. } \\
\text { Recommendations } \\
\text { for Healthcare } \\
\text { Providers [52]. }\end{array}$ \\
\hline
\end{tabular}

The mechanisms of action of each drug are briefly described below, and the alerts and actions taken by the various international and national health authorities are developed.

\subsection{Lorcaserin}

Lorcaserin is a drug that acts as an agonist of the 5-HT2C receptor in the Central Nervous System (CNS), particularly in the hypothalamus, this provokes an appetite reduction. This drug is prescribed for chronic management of weight in patients with obesity or overweight with at least one associated condition like hypertension, diabetes or dyslipidemia. It is important to note that this medication is used as adjunctive therapy to a caloric deficit diet along with an increase in physical activity [54].

This drug was approved on June 27, 2012, by the FDA, but it was not until June 2013, that prescription was enabled for patients in the United States. It began to be marketed under the name of Belviq ${ }^{\circledR}$ by the pharmaceutical company ARENA which years later sold the rights to Eisai Inc. [55]. Later, in 2016 it was released a sustained release formulation called Belviq XR ${ }^{\circledR}$. After that, in 2018 Gutis Ltda. launch in Costa Rica a medicine whose active ingredient is lorcaserin under the name of Relucit ${ }^{\circledR}[56]$.

From the very beginning of its commercialization it has been required a medical prescription, moreover it is a category $\mathrm{X}$ drug, that means this medication is contraindicated in pregnancy, its use in lactation is unknown and it should only be indicated to a certain patient profile, which is why the Ministry of Health of Costa Rica issued a health alert on December 12, 2018, to communicate the correct guidelines for the use of lorcaserin, they establish: the profile that the patient must have for its indication and contraindications, in addition, the need of a prescription for its use and the 
importance of communicate to the treating doctor, pharmacist or nutritionist about any health problem during treatment so that it can be reported to the Pharmacovigilance National Center [56].

On January 14, 2020, the FDA issued an alert about the possible increase in cancer risk, shown in clinical safety studies, however, they cannot conclude the cause of the cancer, therefore, they only made a warning to health professionals and patients of the risk to which they are exposed, and communicate that they will continue reviewing the clinical trials to determine final conclusions [57].

Approximately one month later, on February 13, 2020, the FDA makes a final decision with the review of the clinical safety studies presented, which is that the risks of lorcaserin outweigh its benefits, therefore, requests the company Eisai Inc. the voluntary withdrawal of the drugs Belviq ${ }^{\circledR}$ and Belviq XR $\AA$ from the market. In addition to that the FDA recommends that patients stop consuming the medication and ask health professionals about alternatives, moreover, it asks health professionals to stop prescribing and dispensing lorcaserin. Finally, it recommends patients who have received this treatment to undergo a standard cancer scan [17].

Based on the decision made by the FDA, the Brazilian National Health Surveillance Agency issued an alert on the potential risk of cancer development from the use of Lorcaserin (Belviq ${ }^{\circledR}$ ), along with that, it suspended the prescription of the drug. Also on February 14, 2020, requested the company responsible for the sanitary registration of the product in the country to suspend its marketing [18].

On March 11, 2020, the Costa Rican Ministry of Health, based on the FDA alert, communicated the cancellation of the registration and the withdrawal of lorcaserin from the Costa Rican drug market. The same recommendations made by the FDA for both patients and health professionals are made in the statement. Among the products that were registered and whose active ingredient was lorcaserin are: Relucit $($, Obesilox $₫$ and Repentil@ [16].

\subsection{Pregabalin - Gabapentin}

Gabapentin is a drug that acts on voltage dependent calcium channels; however, the mechanism of action has not been fully elucidated. It is indicated for neuropathic pain and as an addition to other antiepileptics in the treatment of partial and generalized tonic-clonic seizures in patients older than 12 years. This drug was approved in 2000 by the FDA under the brand name Neurontin $®$, by the pharmaceutical company Parke-Davis [58].

Pregabalin binds to the alpha-2-delta subunit of voltage-dependent calcium channels in the central nervous system, inhibiting the release of excitatory neurotransmitters into the synaptic space. It is indicated for the treatment of neuropathic pain and as additional therapy in focal partial seizures. It was approved in 2004 by the FDA under the brand name Lyrica ${ }^{\circledR}$ by the pharmaceutical company Pfizer [59].

On October 15, 2018, the Medicines and Healthcare Regulatory Agency issued a statement on the reclassification of drugs gabapentin and pregabalin into class $\mathrm{C}$, controlled drugs under the Drug Abuse Act, this Reclassification was carried out in April 2019. The agency took this action because the Advisory Council on Drug Abuse communicated concerns about the misuse and addiction caused by these drugs, which has increased the number of fatalities. With the reclassification carried out, it becomes illegal to possess or sell any of these two drugs without a prescription physically signed by a doctor, and once the prescription has been made it has a validation period of 28 days [20].

In the United States, the FDA issued an alert on December 19, 2019, to communicate about serious respiratory problems from the use of pregabalin and gabapentin, especially in patients who show respiratory risk factors, such as chronic obstructive pulmonary disease and those who also use opioids or central nervous system depressant drugs. Additionally, older adult patients are considered high risk [19].

The FDA has determined that the prescription of these drugs has increased as well as their misuse and abuse. For this reason, it has requested the addition of new warnings on the risk of respiratory depression into the dossiers, as well as the request to the manufacturers to carry out clinical trials to evaluate in more detail the potential abuse, especially in combination with opioids. At the moment, not much evidence of respiratory problems has been collected in healthy patients taking these drugs alone, so they communicate that they will continue monitoring [19].

The FDA suggests to healthcare professionals starting these drugs at the lowest dose and monitoring patients for symptoms of respiratory depression when prescribed together with opioids or other central nervous system depressants, such as benzodiazepines, also when they have respiratory risk factors or elderly patients [19]. 
As of the revision date, the Costa Rican Ministry of Health has not issued an alert about severe respiratory problems when using pregabalin or gabapentin concomitantly with other central nervous system depressant medications, nor about the potential abuse and misuse that has been increasing in other countries.

\subsection{Ondansetron}

Ondansetron is a selective 5-HT3 receptor antagonist indicated for nausea and vomiting caused by chemotherapy, cytotoxic radiation therapy or postoperative nausea and vomiting [20].

The WHO Pharmaceuticals NEWSLETTER in 2020 published on the announcement made by the UK Medicines and Healthcare Products Regulatory Agency (MHRA) that exposure to ondansetron during the first three months of pregnancy increases the risk of cleft lip and/or palate in the baby. The MHRA indicated that several epidemiological studies have shown an increased risk of orofacial malformations in newborns of women who were treated with ondansetron early in pregnancy. The recommendation issued by this agency to manage the alert was to limit the use of ondansetron in the early stages of pregnancy to medical and patient judgment previously informed of the potential benefits and risks to both her and the fetus [21,23].

On October 14, 2019, the Costa Rican Ministry of Health issued an information note based on a communiqué issued by the Spanish Agency for Medicines and Health Products (AEMPS) and a study carried out by the European Committee for Risk Assessment in Pharmacovigilance, in which the risk of orofacial closure defects such as cleft lip and palate related to the use of ondansetron during the first trimester of pregnancy (an unauthorized but frequently used indication) was exposed. As measures, the National Center for Pharmacovigilance recommended that health professionals should not prescribe any medication containing Ondansetron to women during the first 12 weeks, assess a change in medication in pregnant patients who have been prescribed Ondansetron, inform women of childbearing age who are on Ondansetron treatment, and report any suspected adverse effects from the use of Ondansetron. In addition, the Ministry of Health indicated that the new safety information should be added to the monograph and package leaflet of all medicines containing Ondansetron in their formulation [22].

\subsection{Ranitidine}

Ranitidine is a histamine $\mathrm{H} 2$ antagonist licensed for gastric ulcer, duodenal ulcer and gastroesophageal reflux disease [60].

On October 17, 2019 the Australian Therapeutic Goods Administration warned of the presence of NNitrosodimethylamine (NMDA) in drugs containing ranitidine. NMDA is a substance that is categorized as a possible carcinogen, as several studies have shown that its long-term use increases the risk of cancer. In the publication made in their website they indicate that among the measures taken is the withdrawal of these products from the Australian market. Also, in the alert they indicate to the patients that they should look together with the doctor or health professional for another treatment alternative for their condition in case they are using medicines with ranitidine and to the health professionals not to indicate or recommend products with ranitidine by mouth. On April 2, 2020 the alert was updated to inform that after further investigation a decision was made to suspend the health registration of all medicines containing ranitidine [24].

The FDA announced on its website on September 24, 2019 the voluntary recall of Sandoz® ranitidine capsules, after detecting the presence of N-Nitrosodimethylamine. In this document the FDA states that it is taking steps with ranitidine manufacturers to keep the public informed of other product recalls and the possible risks of taking ranitidine-containing medications. It also recommends that patients who use the drug in question follow the withdrawal instructions and contact their doctor to consider another treatment for their condition. Patients who take other brands of ranitidine are advised to continue using it but should contact their doctor if they wish to change it [26].

On October 4, 2019, the National Institute for Drug and Food Surveillance (Invima) of Colombia published a health alert outlining the measures implemented due to the presence of NDMA in products with ranitidine and the voluntary withdrawal of lots 1728200002 and 1726100008 of Zantac $₫$ syrup manufactured by the company GlaxoSmithKline Colombia S.A. It indicates to the community in general that if it knows any establishment that distributes or markets the medicine Zantac® syrup it must inform Invima, if it presents some adverse event by the use of this product it must report in the page Web of Invima in: "Medicines and biological products" - "report adverse events for patients" and that if it consumes this medicine it communicates with its doctor to look for the change of product. In addition, the distributors and marketers are requested to stop the distribution and marketing of this medicine and the National Network of Pharmacovigilance urges them to carry out an exhaustive search for the detection of adverse reactions related to this product [27]. 
On October 7, 2019, the Ministry of Health of Costa Rica issued a health alert, based on studies by different International Regulatory Authorities such as the FDA, in which it communicates to the general population and health professionals the identification of N-Nitrosodimethylamine (NDMA), in several batches of medicines containing ranitidine as an active ingredient. Despite the fact that with the information gathered there is no evidence that this chemical has caused harm to patients, the imminent risk associated with its cumulative use made it necessary for the Ministry of Health to take the decision to withdraw from the market all oral medicines containing ranitidine. In view of this measure, pharmaceutical laboratories must withdraw distributed batches and pharmacies must keep the product in quarantine until it is returned. In addition, the general population should not initiate treatment with ranitidine-containing medications, should contact their physician if they are being treated with this drug and report any adverse effects related to the use of this drug [25].

\subsection{Pioglitazone}

Pioglitazone is a molecule of the thiazolidinediones family, which are ligands activated by peroxisomal proliferators receptors (PPARs). Pioglitazone promotes glycemic control in type 2 diabetes patients, by improving insulin sensitivity and modifying the lipid metabolism [61]. It was approved by the FDA in 1999, under the name Actos ${ }^{\circledR}$ from Takeda America Research \& Dev. Ctr. Inc [62].

On December 12, 2016, after a review, the FDA concluded that the use of pioglitazone is related to an increased risk of bladder cancer, because of this the labels of the products that contain this active principle must have the warnings to this risk. The alert about this possible risk was generated in September 2010 and June 2011. As a recommendation for health professionals, the FDA recommends that this active principle should not be used in patients with active bladder cancer and in patients with medical records of this type of cancer, the risks and benefits of this product must be considered [29].

In Costa Rica, the Ministry of Health issued the security alert of this product in January 11, 2017, where it indicated the increased risk of bladder cancer and as recommendations to health professionals established that pioglitazone should not be used in active bladder patients and risks and benefits should be considered in patients with record of this type of cancer. The National Center for Pharmacovigilance should be informed about any side effects when using this or other products. As recommendations to patients, the Ministry of Health indicates that before consuming this medication, patients should inform if they have any medical history or have symptoms such as blood in urine, worsening urination or pain when urinating, as they could be due to bladder cancer, also they should indicate any side effects they present with this or other medications [28].

\subsection{Denosumab}

Denosumab is a fully humanized monoclonal antibody, which binds to the RANK ligand, preventing this ligand from activating RANK which is a receptor of the osteoclast surface. Due to the decrease of the union between RANK-RANKL the formation, function and survival of the osteoclast are inhibited, the bone resorption decreases while bone mass increases [63]. Amgen obtained FDA approval for its commercialization on January 6, 2010, under the name of Prolia ${ }^{\circledR}$ [64].

On May 4, 2017, the National Health Surveillance Agency (ANVISA), reported the identification of a new adverse reaction on clinical studies, corresponding to multiple vertebral fractures after treatment discontinuation of Xgeva ${ }^{\circledR}$ and Prolia ${ }^{\circledR}$. The actions taken by Amgen were to update the reference safety information of the products, including in the informed consent form of the patients the risks that could be caused by this treatment. As this was a clinical study, the researchers also took actions, which were to inform the patients (control group and study group) of the safety recommendations for this product and for the patients receiving treatment with denosumab, it was necessary to certify that this information was documented in their medical records [33].

On June 22, 2018, the United Kingdom through its MRHA agency reported cases of patients who presented clinically significant hypercalcemia after discontinuing treatment with denosumab. It was implemented that the patients should be monitored for signs and symptoms of hypercalcemia after discontinuation of denosumab, in addition, periodic evaluation of serum calcium should be considered and the requirements for supplementation with calcium and vitamin D should be reevaluated [31].

On March 19, 2019 the WHO and the Japanese health agency (MHLW/PMDA) reported two security alerts after discontinuation of denosumab treatment: the appearance of hypercalcemia and multiple vertebral fractures. They established that patients should be monitored and advised of the signs and symptoms of hypercalcemia and vertebral 
fractures after discontinuing denosumab and avoids its use in growing patients [30,32]. In Costa Rica, as of the revision date, the Ministry of Health has not issued any alert regarding these adverse effects.

\subsection{Vortioxetine - Ticagrelor}

Vortioxetine is an antidepressant drug, more specifically a selective serotonin reuptake inhibitor, serotonin 5-HT1A receptor agonist, and serotonin 5-HT3 receptor antagonist [65]. Takeda Pharmaceuticals' drug was approved by the FDA in 2013 [66].

Ticagrelor is an antiplatelet medication, more specifically a non-thienopyridine P2Y12 antagonist used to treat acute coronary syndrome [67], AstraZeneca's drug was approved by the FDA in 2011 [68].

In mid-2015, the FDA issued an alert regarding these medications due to a medication error; the WHO included it in its respective bulletin. The drugs' names caused confusion both for doctors when prescribing and for pharmacists at the time of dispensing. In the alert, professional prescribers are recommended to write the commercial brand of the medicine, in addition to the name of the active ingredient and the indication for use.

In addition, patients who know their medication are recommended to ensure that the one they receive is the correct one at the time of prescription and dispensing. This alert does not indicate that the confusion has reached the ingestion of the wrong medication, that is, at the dispensing process the correction is made or patients recognize the error in the medication they receive [34]. However, in May 2016 the FDA approved the name change for Brintellix $\AA$ to Trintellix $®$ in the US, which began to be marketed under that name in June 2016. They also warn that due to the need to change secondary packaging, it will continue to be marketed with the name of Brintellix ${ }^{\circledR}$ until the shortage of these packages, so it is recommended to continue with the previous recommendations. They indicate that the national drug code also changes [66].

The College of Pharmacists of Santa Fe, Argentina included the FDA alert in August 2015 in one of its documents entitled "Notification of medication errors" which is intended for health professionals in which it indicates only the problem associated with medication error reports. At the time, the change of name for vortioxetine had not been communicated. This document communicates the preventive measures expressed by the FDA [36].

In Chile, the confusion of medications is warned in May 2016 in the pharmacovigilance bulletin No. 7, indicating that both product names are marketed in the country, so, doctors, pharmacists and patients should be alert to the prescription and dispensation [37].

The Government of Peru warns about the alert and the name change of vortioxetine through the electronic portal of the National Center for Documentation and Information on Medicines in May 2016, clarifying that the recommendations regarding the correct prescription and dispensation should continue to be applied [55].

To date, the Costa Rican Ministry of Health has not issued or shared an alert regarding medications. It is important to mention, even, that Brintellix $®$ was registered in the country in 2019 , when the name change to Trintellix $®$ had already been processed by the FDA [69]. Brilinta ${ }^{\circledR}$ has also been registered in the country since 2017 [70]. There are no documents indicating the reason why the same process has not been carried out regarding the change of name of Brintellix®.

\subsection{Ivabradine}

Ivabradine is a selective and specific inhibitor of HCN channels in the sinoatrial node in the heart, slowing down its firing. It is used to reduce the risk of hospitalization in patients with heart failure [71] and treat coronary artery disease and angina symptoms, among others [39], approved by The Therapeutic Goods Administration in Australia in 2010 [40].

The Therapeutic Goods Administration in Australia carried out a review in June 2014 regarding the results obtained in the SIGNIFY study for Ivabradine and placebo, however they indicate that these are being evaluated at the time of publication of the alert. They raise some recommendations for patients and health professionals related to heart rate, dizziness, fatigue, low blood pressure and the need to seek medical help if they present them [72].

The European Medicines Agency, for its part, carried out an update of the data corresponding to the safety of the medicine (Corlentor $\AA / P r o c o r a l a n \AA)$ in November 2014 by the Committee for the Evaluation of Risks in Pharmacovigilance (PRAC), which led to make a series of recommendations in patients who are treated with the drug. These safety data are also based on the findings found through the SIGNIFY study regarding the significant increase in 
the combined risk of cardiovascular death or non-fatal infarction with ivabradine compared to placebo, in addition to an increased risk of bradycardia [41].

The TGA finalized the update of the results in June 2015 indicating the findings of the SIGNIFY study regarding the significant increase in the combined risk of cardiovascular death or non-fatal infarction with ivabradine when compared to placebo, in addition to an increased risk bradycardia. For which the EMA and TGA report that: the clarification is made regarding the doses used in the study, since they are higher than the maximum allowed dose, remembering that it is used from $5 \mathrm{mg}$ bid for angina and up to $7.5 \mathrm{mg}$ bid, if the treatment does not improve the patient's condition within 3 months, it should be discontinued, if the patient's resting beats per minute at the start of the treatment are greater than 70, the medication can be administered. If at any time during treatment it drops to 50, treatment should be discontinued, it should not be used together with verapamil or diltiazem, and the patient should be monitored frequently to assess the contraction of the upper chambers of the heart and the development of atrial fibrillation [41,73].

The Ministry of Health of the Republic of Costa Rica issues one month after the update of the European Medicines Agency in November 2014, through the National Center for Pharmacovigilance, communicating to health personnel about the new restrictions regarding the use of the drug and clarifies point by point the new approved indications for the drug and the findings of the SIGNIFY study and takes as reference the EMA publication [40].

Procoralan® has been registered in the country since 2017 [74].

The Government of the United Kingdom shared the new indications of the medicine (Procoralan) in December 2014 of the publication of the EMA through the Regulatory Agency for Medicines and Health Products, also indicated that a letter is sent to health professionals with the material of interest in the same month [44].

The WHO takes the publication of the alert issued by the TGA and indicates the findings of the SIGNIFY study and the indications approved for the drug in 2015 [41].

The Spanish Agency for Medicines and Health Products for its part issued a statement in November 2014 from the publication of the EMA, where it also summarizes the results obtained in the SIGNIFY study and highlights the new indications for use established [45].

In Colombia, the alert was shared through the National Institute for Food and Drug Surveillance in 2015, which takes the information from the EMA publication. In this document they indicate the new indications and recommendations such as not changing the doses of the medication without consulting the doctor, not consuming other medications without first consulting the physician, evacuating all doubts regarding treatment and reporting any adverse effects, in addition to saving the medication out of the reach of children [43].

\subsection{Saxagliptin - Alogliptin}

Saxagliptin and alogliptin are drugs used for the treatment of type 2 diabetes mellitus, which act by inhibiting the enzyme dipeptidyl peptidase 4 (DPP-4), increasing the levels of active incretin [75,76]. These medications, along with diet and exercise, lower blood sugar levels [46].

In May 2016, the FDA issued an alert about the possible risk of heart failure related to the use of drugs with the active ingredients saxagliptin or alogliptin. Saxagliptin-containing medications include Onglyza ${ }^{\circledR}$ and Kombiglyze XRß, both from the AstraZeneca laboratory; while for alogliptin Nesina ${ }^{\circledR}$, Kazano ${ }^{\circledR}$ and Oseni ${ }^{\circledR}$ from Takeda laboratory are mentioned [46]. Of all the medications mentioned above, only Kombiglyze XRß is available in Costa Rica [48]. This alert was referenced in one of the 2016 WHO drug newsletters [47].

The alert issued by the FDA in 2016 is an update of a statement made by this same entity in November 2014, in which it asks the manufacturer of the drugs that contain the active ingredient saxagliptin for a clinical study to assess the possible relationship that its use with heart failure [77]. This request was made due to the results of the study "Saxagliptin and cardiovascular outcomes in patients with type 2 diabetes mellitus" published in the 2013 New England Journal of Medicine (NEJM), which reports a higher rate of hospitalization for heart failure in patients who uses the drug saxagliptin $[77,78]$.

To make the decision, the FDA analyzed 2 clinical studies, SAVOR and EXAMINE, both of which showed evidence that saxagliptin and alogliptin increase the risk of hospitalization for heart failure compared to placebo. These studies were also discussed at the FDA's Endocrinologic and Metabolic Medicines Advisory Committee meeting in April 2015 
$[46,79,80]$. Given these results, the FDA decided to add the potential risk of heart failure to the labels of these medications. If a patient taking these medications experiences difficulty breathing while lying down, tiredness, weakness, fatigue, shortness of breath when performing routine activities, or weight gain with swelling in the ankles, feet, legs, or stomach, they should consult a health professional. Health personnel are advised to consider discontinuing the medication if patients develop heart failure [46].

In Costa Rica, the Ministry of Health issued a safety alert in September 2016 about the active substance saxagliptin due to the increased risk of heart failure. The reason why the alert in Costa Rica was made specifically to saxagliptin is because alogliptin is not registered in the country. Still, the Ministry of Health statement refers to the FDA alert on the 2 drugs (saxagliptin and alogliptin) and their possible risk of heart failure. Health professionals are advised to: inform patients of the possible risk, identify any risk factors for hospitalization for heart failure, consider the risk benefit before starting therapy, discontinue medications in patients who develop heart failure, and do the Report of adverse reactions to the Pharmacovigilance Center. Patients are advised to report any adverse effects to their doctor and not to stop taking it unless their doctor tells them to.[48].

In Brazil, ANVISA, issued a security alert in May 2016 on the drugs Onglyza ${ }$ and Kombiglyze XRß, both with the active ingredient saxagliptin made by AstraZeneca. The alert makes reference to the SAVOR study and the addition of the warning on the label of the drugs, including the most common signs and symptoms of heart failure [49].

The Peruvian Ministry of Health made a statement about the FDA's initial alert in 2014. Reference is made to the NEJM study and the increase in the hospitalization rate, but no information was found about the 2016 alert issued by the FDA [81].

\subsection{Lamotrigine}

Lamotrigine is a medicine used to treat seizures and maintenance treatment in patients with bipolar disorder, which obtained its first approval by the FDA in 1994 under the name Lamictal by GlaxoSmithKline [50]. Inhibits glutamate release and inhibits voltage dependent sodium channels. Has a weak inhibitory effect on 5-HT3 [82].

On April 25, 2018, the FDA issued an alert about an immune system reaction called hemophagocytic lymphohistiocytosis (HLH), rare but very serious due to the use of lamotrigine. For this reason, the FDA requested the addition of a new warning on the labels of the drug indicating this risk [50].WHO included this FDA alert in one of its 2018 drug newsletter [51].

The most characteristic manifestations of HLH are fever, edema, hemocytopenia, increased concentrations of liver enzymes, hypofibrinogenemia, neurological disorders, hypertriglyceridemia, elevated blood levels of CD25, decreased activity of cytolytic lymphocytes, hemophagocytosis, elevated levels of blood ferritin. For these reasons, if a patient has any of the symptoms shown above or unusual pain, swelling, or tenderness in the upper right abdomen, rashes, yellow skin and eyes, bleeding, difficulty walking, seeing, or even seizures, it should be assist health personnel immediately for physical exams and laboratory tests [50,83].

The FDA mentions the importance of making a good diagnosis, since HLH can be confused with other immunological reactions such as DRESS syndrome [50]. An alert about this syndrome appears along with the HLH reaction, both being produced by the use of lamotrigine, in the 2018 WHO bulletin mentioned above. The bulletin mentions that the Ministry of Food and Drug Safety of the Republic of Korea added in the insert of lamotrigine the reaction with eosinophilia and systemic symptoms (DRESS syndrome) as one of the possible adverse effects [51]. At the present, the adverse effect of HLH from the consumption of lamotrigine is documented but its frequency has not been determined. [82].

In Colombia, Invima issued an alert a month after the FDA, stating that the use of lamotrigine can cause HLH, which is an over-response of the immune system. His case resolution was to include on the drug label information about the risk of HLH, which can be fatal, and on the insert information about what the symptoms of this reaction may be and information for health professionals about the diagnosis, warning about the confusion with DRESS syndrome, when to discontinue the drug and advising the patient is recommended. In addition, the alert provides a pharmacovigilance report of adverse reactions associated with the use of lamotrigine that runs from January 2002 to April 2018 [52].

In Peru, the National Center for Drug Documentation and Information, made an alert a day after the FDA, where the possible adverse effect of HLH is reported and recommended that patients not stop taking the drug without the doctor's instructions [53]. 
This safety alert is the fourth reported by the FDA for lamotrigine. It had previously been linked to cleft lip in newborns in September 2006, suicidal thoughts and behaviors along with other anti-seizure medications in May 2009, and an aseptic meningitis warning in August 2010 [50]. The Costa Rican Ministry of Health issued an official statement only for the aseptic meningitis in November 2010 [84].

\section{Conclusion}

It was determined that the actions taken by the health authorities at a national and international level are based on the severity of the effect related to the drug and the risk-benefit obtained in the clinical studies that support the health alert issued.

This review showed that scientifically based identification of a drug related effect occurs years after the product enters the market, thus post-registration pharmacovigilance, required by authorities from the pharmaceutical industry, is a useful tool in prevention.

Health alerts, issued in Costa Rica, for drug related effects are based in alerts issued by international regulatory organizations such as WHO and FDA, where the Costa Rican Ministry of Health adapts the information from these alerts to the Costa Rican population and situation, however, of the ten alerts analyzed, four were not issued in Costa Rica.

\section{Compliance with ethical standards}

\section{Acknowledgments}

This research work was carried out during the course Fundamentos de Farmacoepidemiología. We would like to thank Dr. Milania Rocha, coordinator of the course, and Dr. Victoria Hall, collaborating professor, for their support and for guiding this research.

\section{Disclosure of conflict of interest}

All authors declare that there is no conflict of interest.

\section{References}

[1] Ministerio de Salud Costa Rica. Farmacovigilancia [Internet]. Costa Rica: Ministerio de Salud; (C2016. Available from https://www.ministeriodesalud.go.cr/index.php/regulacion-de-la-salud/farmacovigilancia

[2] Valsecia M. Farmacovigilancia y Mecanismos de Reacciones Adversas a Medicamentos [Internet]. Argentina: Universidad Nacional del Nordeste; n.d. https://med.unne.edu.ar/sitio/multimedia/imagenes/ckfinder/files/files/13_farmacovigi.pdf

[3] Shibbiru T, Tadesse F. Adverse Drug Reactions: An Overview. J. Journal of Medicine, Physiology and Biophysics. 2016; 9 (23): 7-14.

[4] Coleman JJ, Pontefract SK. Adverse drug reactions. Clinical Medicine Journal. 2016; 16 (5): $481-485$.

[5] Payne R, Slight S, Franklin BD, Avery AJ. World Health Organization. World Health Organization, Department of Service Delivery and Safety, Medication errors. 2016.

[6] Aronson JK. Medication errors. definitions and classification. British Journal of Clinical Pharmacology. 2009; 67: 599-604.

[7] Williams DJP. Medication errors. The Journal of the Royal College of Physicians of Edinburgh. 2007; 37(4): 343346.

[8] World Health Organization. Substandard and falsified medical products [Internet].Western Pacific Union: World Health Organization. (C)2020. Available from https://www.who.int/westernpacific/health-topics/substandardand-falsified-medical-products

[9] Li R, Curtain C, Bereznicki L, Zaidi STR. Community pharmacists' knowledge and perspectives of reporting adverse drug reactions in Australia: a cross-sectional survey. International Journal of Clinical Pharmacy. 2018; 40: 878-889. 
[10] Van Grootheest AC, De Jong-van den Berg LW. The role of hospital and community pharmacists in pharmacovigilance. Research in Social and Administrative Pharmacy. 2005; 1(1): 126-133.

[11] World Health Organization. The Importance of Pharmacovigilance: safety monitoring of medicinal products [Internet]. United Kingdom: World Health Organization. (C2002. Available from https://apps.who.int/iris/handle/10665/42493.

[12] Cuevas IE. Presente y futuro de la farmacovigilancia en la Industria Farmacéutica. Vaccimotor. 2007; 16(6): 2025.

[13] Jeetu G, Anusha G. Pharmacovigilance: A Worldwide Master Key for Drug Safety Monitoring. Journal of Young Pharmacists. 2010; 2(3):315-320.

[14] Procuraduría General de la República. Reglamento del Sistema Nacional de Farmacovigilancia [Internet]. Costa Rica: Procuraduría General de la República; (C2009. Available from http://www.pgrweb.go.cr/scij/Busqueda/Normativa/Normas/nrm_texto_completo.aspx?param1=NRTC\&nVal or1=1\&nValor $2=65500 \&$ nValor3=76559\&strTipM=TC

[15] Instituto Clodomiro Picado. Farmacovigilancia [Internet]. Costa Rica: Universidad de Costa Rica; C2020. Available from http://www.icp.ucr.ac.cr/es/servicios-y-productos/farmacovigilancia

[16] Ministerio de Salud Costa Rica. Cancelación de Registro Sanitario y Retiro del Mercado de Lorcaserina [Internet]. Costa Rica: Ministerio de Salud; (C2020. Available from https://www.ministeriodesalud.go.cr/index.php/centrode-prensa/noticias/741-noticias-2020/1587-centro-nacional-de-farmacovigilancia-nota-informativa-01-20cancelacion-de-registro-sanitario-y-retiro-del-mercado-de-lorcaserina

[17] Food and Drug Administration. FDA requests the withdrawal of the weight-loss drug Belviq, Belviq XR (lorcaserin) from the market [Internet]. United States of America: Food and Drug Administration; (C2020. Available from https://www.fda.gov/drugs/drug-safety-and-availability/fda-requests-withdrawal-weight-lossdrug-belviq-belviq-xr-lorcaserin-market

[18] Agência Nacional de Vigilância Sanitária. Anvisa a gerência de farmacovigilância alerta para o risco potencial de ocorrência de neoplasias com o uso do medicamento belviq® (lorcasserina) [Internet]. Brasil: Agência Nacional de Vigilância Sanitária; C2020. Available from http://portal.anvisa.gov.br/informacoes-tecnicas13//asset_publisher/WvKKx2fhdjM2/content/a-gerencia-de-farmacovigilancia-alerta-para-o-risco-potencial-deocorrencia-de-neoplasias-com-o-uso-do-medicamento-belviq-lorcasserina-

/33868?p_p_auth=BOttB4WI\&inheritRedirect=false\&redirect=http\%3A\%2F\%2Fportal.anvisa.gov.br\%2Finfor macoes-

tecnicas13\%3Fp_p_auth\%3DBOttB4WI\%26p_p_id\%3D101_INSTANCE_WvKKx2fhdjM2\%26p_p_lifecycle\%3D0 \%26p_p_state\%3Dnormal\%26p_p_mode\%3Dview\%26p_p_col_id\%3D_118_INSTANCE_EikhC3EOkiln_column1\%26p_p_col_pos\%3D1\%26p_p_col_count\%3D3

[19] Food and Drug Administration. FDA warns about serious breathing problems with seizure and nerve pain medicines gabapentin (Neurontin, Gralise, Horizant) and pregabalin (Lyrica, Lyrica CR)[Internet]. United States of America: Food and Drug Administration; (C)2019. Available from https://www.fda.gov/drugs/drug-safetyand-availability/fda-warns-about-serious-breathing-problems-seizure-and-nerve-pain-medicines-gabapentinneurontinhttps://www.fda.gov/drugs/drug-safety-and-availability/fda-warns-about-serious-breathingproblems-seizure-and-nerve-pain-medicines-gabapentin-neurontin

[20] Medicines \& Healthcare products Regulatory Agency. Pregabalin and gabapentin to be controlled as class C drugs[Internet]. United Kingdom: Medicines \& Healthcare productsRegulatory Agency; (C2018. Available from https://www.gov.uk/government/news/pregabalin-and-gabapentin-to-be-controlled-as-class-c-drugs

[21] Medicines \& Healthcare products Regulatory Agency. Ondansetron: small increased risk of oral clefts following use in the first 12 weeks of pregnancy [Internet]. United Kingdom: Medicines \& Healthcare products Regulatory Agency; (C2020. Available from https://www.gov.uk/drug-safety-update/ondansetron-small-increased-risk-oforal-clefts-following-use-in-the-first-12-weeks-of-pregnancy.

[22] Ministerio de Salud Costa Rica. Nota Informativa 02-19. Nueva Información de Seguridad para Ondansetrón [Internet]. Costa Rica: Ministerio de Salud; (C)2019. Available from https://www.ministeriodesalud.go.cr/index.php/consulta-de-alertas-de-seguridad/4463-14-de-octubre-de2019-nota-informativa-02-19-nueva-informacion-de-seguridad-para-ondansetron/file.

[23] World Health Organization. WHO Pharmaceuticals NEWSLETTER N 4 [Internet]. Switzerland: World Health Organization. (C2020. Available from https://www.who.int/publications/i/item/9789240010741 
[24] Therapeutic Goods Administration. Ranitidine. Updates- Contamination with N-nitrosodimethylamine [Internet]. Australia: Department of Health; (C2020. Available from https://www.tga.gov.au/alert/ranitidine-0

[25] Ministerio de Salud Costa Rica. Alerta Sanitaria: Retiro del mercado de medicamentos que contienen ranitidina vía oral [Internet]. Costa Rica: Ministerio de Salud; (C2019. Available from https://www.ministeriodesalud.go.cr/index.php/noticias/noticias-2019/1487-alerta-sanitaria-retiro-delmercado-de-medicamentos-que-contienen.

[26] Food and Drug Administration. FDA News Release: La FDA anuncia el retiro voluntario del mercado de las cápsulas de ranitidina Sandoz, tras detectarse una impureza [Internet]. United States of America: Food and Drug Administration; (C2019. Available from https://www.fda.gov/news-events/press-announcements/la-fdaanuncia-el-retiro-voluntario-del-mercado-de-las-capsulas-de-ranitidina-sandoz-tras-detectarse.

[27] Instituto Nacional de Vigilancia de Medicamentos y Alimentos. ALERTA SANITARIA: Zantac jarabe lotes 1728200002 y 1726100008 [Internet]. Colombia: Instituto Nacional de Vigilancia de Medicamentos y Alimentos; (C) 2019 . Available from https://app.invima.gov.co/alertas/ckfinder/userfiles/files/ALERTAS\%20SANITARIAS/medicamentos_pbiologi cos/2019/Octubre/Alerta\%20No_\%20\%23149-2019\%20\%20Zantac\%20jarabe\%20lotes\%201728200002\%20y\%201726100008\%20.pdf

[28] Ministerio de Salud Costa Rica. Nueva información de seguridad con el uso del principio activo Pioglitazona [Internet]. Costa Rica: Ministerio de Salud; (C2017. Available from https://www.ministeriodesalud.go.cr/index.php/consulta-de-alertas-de-seguridad/3193-11-de-enero-de2017-informacion-de-seguridad-con-el-uso-del-principio-activo-pioglitazona/file.

[29] Food and Drug Administration. FDA Drug Safety Communication: Updated FDA review concludes that use of type 2 diabetes medicine pioglitazone may be linked to an increased risk of bladder cancer [Internet]. United States of America: Food and Drug Administration; (C2016. Available from https://www.fda.gov/drugs/drug-safetyand-availability/fda-drug-safety-communication-updated-fda-review-concludes-use-type-2-diabetes-medicinepioglitazone

[30] World Health Organization. WHO Pharmaceuticals NEWSLETTER N³ [Internet]. Switzerland: World Health Organization. (C)2019. Available from https://www.who.int/medicines/publications/PharmaNewsletter319/en/

[31] Medicines \& Healthcare products Regulatory Agency. Denosumab (Xgeva) for giant cell tumour of bone: risk of clinically significant hypercalcaemia following discontinuation [Internet]. United Kingdom: Medicines \& Healthcare products Regulatory Agency; C2018. Available from https://www.gov.uk/drug-safetyupdate/denosumab-xgeva-for-giant-cell-tumour-of-bone-risk-of-clinically-significant-hypercalcaemiafollowing-discontinuation

[32] Pharmaceuticals and Medical Devices Agency. Summary of Investigation Results Denosumab (genetical recombination) (120 mg product) [Internet]. Japan: Pharmaceuticals and Medical Devices Agency; (C2019. Available from https://www.pmda.go.jp/files/000228669.pdf

[33] Agência Nacional de Vigilância Sanitária. Xgeva® (denosumabe) - Nova reação adversa identificada em estudos clínicos. Amgen, 04 de maio de 2017 (Versão 1.3) [Internet]. Brasil: Agência Nacional de Vigilância Sanitária; (C2017. Available from http://portal.anvisa.gov.br/resultado-debusca?p_p_id=101\&p_p_lifecycle=0\&p_p_state=maximized\&p_p_mode=view\&p_p_col_id=column$1 \&$ p_p_col_count $=1 \& \_101$ _struts_action=\%2Fasset_publisher $\% 2$ Fview_content $\&$ 101_assetEntryId=3409869\& _101_type=document\&redirect=http $\% 3 \mathrm{~A} \% 2 \mathrm{~F} \% 2$ Fportal.anvisa.gov.br\%2Fresultado-debusca\%3Fp_p_id\%3D3\%26p_p_lifecycle\%3D0\%26p_p_state\%3Dnormal\%26p_p_mode\%3Dview\%26p_p_col_i d\%3Dcolumn-

1\%26p_p_col_count\%3D1\%26_3_groupId\%3D0\%26_3_keywords\%3Ddenosumab\%26_3_cur\%3D1\%26_3_stru ts_action\%3D\%252Fsearch\%252Fsearch\%26_3_format\%3D\%26_3_formDate\%3D1441824476958

[34] Food and Drug Administration. FDA Drug Safety Communication: FDA warns about prescribing and dispensing errors resulting from brand name confusion with antidepressant Brintellix (vortioxetine) and antiplatelet Brilinta (ticagrelor) [Internet]. United States of America: Food and Drug Administration; (C2015. Available from https://www.fda.gov/drugs/drug-safety-and-availability/fda-drug-safety-communication-fda-warns-aboutprescribing-and-dispensing-errors-resulting-brand-name 
[35] World Health Organization. WHO Pharmaceuticals NEWSLETTER N5 [Internet]. Switzerland: World Health Organization. (C2015. Available from https://www.who.int/medicines/publications/PharmaNewsletter5_15/en/

[36] Colegio de Farmacéuticos de la provincia de Santa Fe. Brintellix® y Brilinta®. Riesgo de error tipo LASA. FDA [Internet]. Argentina: Colegio de Farmacéuticos de la provincia de Santa Fe; (C2015. Available from: https://colfarsfe.org.ar/2016/11/08/brintellix-y-brilinta-riesgo-de-error-tipo-lasa-fda/

[37] Ministerio de Salud de Chile, Boletín de Farmacovigilancia $N^{\circ} 7$ [Internet]. Chile: Ministerio de Salud de Chile; (C)2016. Available from http://www.ispch.cl/newsfarmacovigilancia/07/boletin07.html

[38] Centro Nacional de Documentación e Información de Medicamentos. La FDA cambió de nombre al Brintellix® (vortioxetine) por Trintellix $®$, para evitar errores de prescripción y dispensación con Brilinta ${ }^{\circledR}$ (ticagrelor) [Internet]. Perú: Centro Nacional de Documentación e Información de Medicamentos; C2016. Available from http://bvcenadim.digemid.minsa.gob.pe/noticias/278-la-fda-cambio-de-nombre-al-brintellix-vortioxetine-portrintellix-para-evitar-errores-de-prescripcion-y-dispensacion-con-brilinta-ticagrelor

[39] Ministerio de Salud Costa Rica. Restricciones de uso para reducir riesgo de problemas cardiácos con el uso de ivabradina [Internet]. Costa Rica: Ministerio de Salud; (C)2014. Available from https://www.ministeriodesalud.go.cr/index.php/consulta-de-alertas-de-seguridad/2608-17-de-diciembre-de2014-nueva-informacion-de-seguridad-sobre-ivabradina/file

[40] Therapeutic Goods Administration. Australian Public Assessment Report for Ivabradine [Internet]. Australia: Department of Health; (C2010. Available from https://www.tga.gov.au/sites/default/files/auspar-coralan.pdf

[41] European Medicines Agency. European Medicines Agency recommends measures to reduce risk of heart problems with Corlentor/Procoralan (ivabradine)[Internet]. European Union: European Medicines Agency; (C)2014. Available from https://www.ema.europa.eu/en/news/european-medicines-agency-recommendsmeasures-reduce-risk-heart-problems-corlentorprocoralan

[42] World Health Organization. WHO Pharmaceuticals NEWSLETTER N ${ }^{\circ} 4$ [Internet]. Switzerland: World Health https://www.who.int/medicines/publications/PharmaNewsletter5_15/en/

[43] Instituto Nacional de Vigilancia de Medicamentos y Alimentos. Ivabradina: información para profesionales de la salud [Internet]. Colombia: Instituto Nacional de Vigilancia de Medicamentos y Alimentos; (C2015. Available from https://app.invima.gov.co/alertas/ckfinder/userfiles/files/INFORMES\%20DE\%20SEGURIDAD/Medicamentos /2015/Enero/IVABRADINA.pdf.

[44] Medicines \& Healthcare products Regulatory Agency. Ivabradine (Procoralan) in the symptomatic treatment of angina: risk of cardiac side effects [Internet]. United Kingdom: Medicines \& Healthcare productsRegulatory Agency; (C)2014. Available from https://www.gov.uk/drug-safety-update/ivabradine-procoralan-in-thesymptomatic-treatment-of-angina-risk-of-cardiac-side-effects

[45] Agencia Española de Medicamentos y Productos Sanitarios. Ivabradina (Corlentor@, Procoralan®): restricciones de uso en pacientes con angina de pecho crónica estable [Internet]. Spain: Agencia Española de Medicamentos y $\begin{array}{llll}\text { Productos } & \text { Sanitarios; } & \text { (C)2014. Available }\end{array}$ https://www.aemps.gob.es/informa/notasinformativas/medicamentosusohumano-3/seguridad-1/2014/nimuh_fv_17-ivabradina/

[46] Food and Drug Administration. FDA Drug Safety Communication: FDA adds warnings about heart failure risk to labels of type 2 diabetes medicines containing saxagliptin and alogliptin [Internet]. United States of America: Food and Drug Administration; (C)2016. Available from https://www.fda.gov/drugs/drug-safety-andavailability/fda-drug-safety-communication-fda-adds-warnings-about-heart-failure-risk-labels-type-2-diabetes

[47] World Health Organization. WHO Pharmaceuticals NEWSLETTER N³ [Internet]. Switzerland: World Health Organization. C) Available from https://www.who.int/medicines/publications/PharmaNewsletter3_16/en/

[48] Ministerio de Salud Costa Rica. Nueva información de seguridad con el uso del principio activo saxagliptina [Internet]. Costa Rica: Ministerio de Salud; (C2016. Available from https://www.ministeriodesalud.go.cr/index.php/consulta-de-alertas-de-seguridad/3112-01-de-setiembre-de2016-nueva-informacion-de-seguridad-con-el-uso-del-principio-activo-saxagliptina/file.

[49] Agência Nacional de Vigilância Sanitária. Onglyza (saxagliptina) y Kombiglyze XR® (saxagliptina y metformina hidrocloruro XR) - Riesgo de insuficiencia cardíaca. AstraZeneca, 8 de junio de 2016 - Cartas a los profesionales 
de la salud [Internet]. Brasil: Agência Nacional de Vigilância Sanitária; (C2016. Available from http://portal.anvisa.gov.br/cartas-aos-profissionais-de-saude/-

/asset_publisher/6Qk8g2SPhy9v/document/id/2824244/rss

[50] Food and Drug Administration. FDA Drug Safety Communication: FDA warns of serious immune system reaction with seizure and mental health medicine lamotrigine (Lamictal) [Internet]. United States of America: Food and Drug Administration; (C)2018. Available from https://www.fda.gov/drugs/drug-safety-and-availability/fdadrug-safety-communication-fda-warns-serious-immune-system-reaction-seizure-and-mental-health

[51] World Health Organization. WHO Pharmaceuticals NEWSLETTER N 3 [Internet]. Switzerland: World Health Organization. (C)2018. Available

from https://www.who.int/medicines/publications/PharmaNewsletter3_18/en/

[52] Instituto Nacional de Vigilancia de Medicamentos y Alimentos. Información de seguridad sobre el principio activo Lamotrigina y su asociación con reacción grave al sistema inmune [Internet]. Colombia: Instituto Nacional de $\begin{array}{llllll}\text { Vigilancia de } & \text { Medicamentos } & \text { y } & \text { Alimentos; } 2018 . & \text { Available from }\end{array}$ https://www.invima.gov.co/documents/20143/851967/INFORME_DE_SEGURIDAD_LAMOTRIGINA.pdf/754fc 22a-ee43-0183-c65c-2c9fea6ba4c3.

[53] Centro Nacional de Documentación e Información de Medicamentos. Linfohistiocitosis hemofagocítica, una reacción adversa grave del sistema inmune con lamotrigina [Internet]. Perú: Centro Nacional de Documentación e Información de Medicamentos; (C2018. Available from http://bvcenadim.digemid.minsa.gob.pe/noticias/370linfohistiocitosis-hemofagocitica-una-reaccion-adversa-grave-del-sistema-inmune-con-lamotrigina

[54] Gustafson A, King C, Rey J. Lorcaserin (Belviq): A Selective Serotonin 5-HT2C Agonist In the Treatment of Obesity. Pharmacy and Therapeutics. 2013; 38(9): 525-534.

[55] Eisai Co., U.S. FDA approves Belviq XR®, a once-daily formulation of lorcaserin for chronic weight management

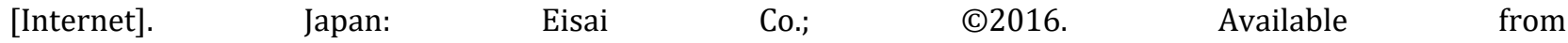
https://www.eisai.com/news/news201652.html\#: :text=Lorcaserin\%20was\%20approved\%20in\%20June,or $\% 20$ greater\%20(overweight)\%20in\%20the

[56] Ministerio de Salud Costa Rica. Medicamento Relucit: Pautas para un Uso Correcto [Internet]. Costa Rica: Ministerio de Salud; (C2018. Available from https://www.ministeriodesalud.go.cr/index.php/alertas/alertapor-productos-en-el-mercado/3983-12-diciembre-2018-alerta-relucit-con-firmas-escaneadas/file

[57] Food and Drug Administration. Safety clinical trial shows possible increased risk of cancer with weight-loss medicine Belviq, Belviq XR (lorcaserin) [Internet]. United States of America: Food and Drug Administration; (C)2020. Available from https://www.fda.gov/drugs/drug-safety-and-availability/safety-clinical-trial-showspossible-increased-risk-cancer-weight-loss-medicine-belviq-belviq-xr

[58] Rose MA, Kam PCA. Gabapentin: pharmacology and its use in pain management: Gabapentin. Anaesthesia. 2002; 57: 451-462.

[59] Taylor CP, Angelotti T, Fauman E. Pharmacology and mechanism of action of pregabalin: The calcium channel $\alpha 2-\delta$ (alpha2-delta) subunit as a target for antiepileptic drug discovery. Epilepsy Research. 2007; 73(2): 137150 .

[60] Uptodate. Ranitidine (United States: Withdrawn from market): Drug information [Internet]. Uptodate; (C2020. Available from https://www-uptodate-com.ezproxy.sibdi.ucr.ac.cr/contents/ranitidine-united-stateswithdrawn-from-market-drug-

information?search=ranitidina\&source=panel_search_result\&selectedTitle=1 82\&usage_type=panel\&kp_tab= drug_general\&display_rank=1.

[61] Smith U. Pioglitazone: mechanism of action. The International Journal of Clinical Practice. 2001; 121: 13-18.

[62] Food and Drug Administration. Actos (Pioglitazone Hydrochloride) Tablets. Drug Approval Package [Internet]. United States of America: Food and Drug Administration; (C2001. Available from https://www.accessdata.fda.gov/drugsatfda_docs/nda/99/021073A_Actos.cfm.

[63] Hanley DA, Adachi JD, Bell A, Brown V. Denosumab: mechanism of action and clinical outcomes. The International Journal of Clinical Practice. 2012: 1139-1146.

[64] Food and Drug Administration. Prolia (denosumab) Injection. Drug Approval Package [Internet]. United States of America: Food and Drug Administration; $\quad$ (C)2010. Available from https://www.accessdata.fda.gov/drugsatfda_docs/nda/2010/125320s0000T0C.cfm 
[65] Uptodate. Vortioxetine: Drug information [Internet]. Uptodate; C2020. Available from https://www-uptodatecom.ezproxy.sibdi.ucr.ac.cr/contents/vortioxetine-drug-

information?search=vortioxetina\&source=panel_search_result\&selectedTitle=1 16\&usage_type=panel\&kp_tab =drug_general\&display_rank=1

[66] Food and Drug Administration. FDA Drug Safety Podcast: FDA approves brand name change for antidepressant drug Brintellix (vortioxetine) to avoid confusion with antiplatelet drug Brilinta (ticagrelor) [Internet]. United States of America: Food and Drug Administration; (C2016. Available from https://www.fda.gov/drugs/fda-drugsafety-podcasts/fda-drug-safety-podcast-fda-approves-brand-name-change-antidepressant-drug-brintellixvortioxetine

[67] Uptodate. Ticagrelor: Drug information [Internet]. Uptodate; C2020. Available from https://www-uptodatecom.ezproxy.sibdi.ucr.ac.cr/contents/ticagrelor-druginformation?search=ticagrelor\&source=panel_search_result\&selectedTitle=1 84\&usage_type=panel\&kp_tab=d rug_general\&display_rank=1

[68] Food and Drug Administration. Drug Approval Package: Brilinta (ticagrelor) NDA \#022433 [Internet]. United States of America: Food and Drug Administration; (C)2011. Available from https://www.accessdata.fda.gov/drugsatfda_docs/nda/2011/0224330rig1s000TOC.cfm.

[69] Ministerio de Salud Costa Rica. Reporte de productos registrados. Brintellix ® [Internet]. Costa Rica: Ministerio de Salud; C2019. Available from http://registrelo.go.cr/cfmx/ms/consultasPublicas/productos_Registrados/reporte.cfm.

[70] Ministerio de Salud Costa Rica. Reporte de productos registrados. Brillinta ${ }^{[}[$Internet]. Costa Rica: Ministerio de $\begin{array}{llll}\text { Salud; } & \text { (C)2019. Available from }\end{array}$ http://registrelo.go.cr/cfmx/ms/consultasPublicas/productos_Registrados/reporte.cfm.

[71] Uptodate. Ivabradine: Drug information [Internet]. Uptodate; (C2020. Available from https://www-uptodatecom.ezproxy.sibdi.ucr.ac.cr/contents/ivabradine-druginformation?search=ivabradina\&source=panel_search_result\&selectedTitle $=1 \sim 40 \&$ usage_type=panel\&kp_tab= drug_general\&display_rank=1\#F27857541

[72] Therapeutic Goods Administration. Ivabradine (Coralan) and cardiovascular events in patients with angina [Internet]. Australia: Department of Health; (C)2015. Available from https://www.tga.gov.au/monitoringcommunication/ivabradine-coralan-and-cardiovascular-events-patients-angina

[73] Therapeutic Goods Administration. Medicines Safety Update Volume 6 Number 3, June 2015 [Internet]. Australia: Department of Health; (C2015. Available from https://www.tga.gov.au/publication-issue/medicines-safetyupdate-volume-6-number-3-june-2015

[74] Ministerio de Salud Costa Rica. Reporte de productos registrados. Procoralan® [Internet]. Costa Rica: Ministerio $\begin{array}{llll}\text { de } & \text { Salud; } 2017 . & \text { Available from }\end{array}$ http://registrelo.go.cr/cfmx/ms/consultasPublicas/productos_Registrados/reporte.cfm.

[75] Uptodate. Saxagliptin: Drug information [Internet]. Uptodate; C2020. Available from - https://www-uptodatecom.ezproxy.sibdi.ucr.ac.cr/contents/saxagliptin-drug-

information?search=saxagliptina\&source=search_result\&selectedTitle=1 27\&usage_type=panel\&kp_tab=drug _general\&display_rank=1

[76] Uptodate. Alogliptin: Drug information [Internet]. Uptodate; @2020. Available from https://www-uptodatecom.ezproxy.sibdi.ucr.ac.cr/contents/alogliptin-druginformation?search=Alogliptina\&source=search_result\&selectedTitle=1 $10 \&$ usage_type=panel\&kp_tab=drug_ general\&display_rank=1

[77] Food and Drug Administration. Drug Safety and Availability - FDA Drug Safety Communication: FDA to review heart failure risk with diabetes drug saxagliptin (marketed as Onglyza and Kombiglyze XR) [Internet]. United States of America: Food and Drug Administration; (C)2014. Available from https://wayback.archiveit.org/7993/20170112031610/http://www.fda.gov/Drugs/DrugSafety/ucm385287.htm

[78] Scirica BM, Bhatt DL, Braunwald E, Steg PG, Davidson J, Hirshberg B, Ohman P, Frederich R, Wiviott SD, Hoffman EB, Cavender MA, Udell JA, Desai NR, Mosenzon O, McGuire DK, Ray KK, Leiter LA, Raz I. Saxagliptin and Cardiovascular Outcomes in Patients with Type 2 Diabetes Mellitus. The New England Journal of Medicine. 2013; 369: 1317-1326. 
[79] Mosenzon O, Raz I, Scirica BM, Hirshberg B, Stahre CI, Steg PG, Davidson J, Ohman P, Price DL, Frederich B, Udell JA, Braunwald E, Bhatt DL. Baseline characteristics of the patient population in the Saxagliptin Assessment of Vascular Outcomes Recorded in patients with diabetes mellitus (SAVOR)-TIMI 53 trial. Diabetes/Metabolism Research and Review. 2013; 29: 417-426.

[80] White WB, Bakris GL, Bergenstal RM, Cannon CP, Cushman WC, Fleck P, Heller S, Mehta C, Nissen SE, Perez A, Wilson C, Zannad F. Examination of cardiovascular outcomes with alogliptin versus standard of care in patients with type 2 diabetes mellitus and acute coronary syndrome (examine): a cardiovascular safety study of the dipeptidyl peptidase 4 inhibitor alogliptin in patients with type 2 diabetes with acute coronary syndrome. American Heart Journal. 2011; 162(4): 620-626.e1.

[81] Ministerio de Salud Perú. Revisión de saxagliptina, debido a riego de insuficiencia cardiaca [Internet]. Perú: Ministerio de Salud; (C2014. Available from https://www.gob.pe/institucion/minsa/noticias/66812-revisionde-saxagliptina-debido-a-riego-de-insuficiencia-cardiaca

[82] Uptodate. Lamotrigine: Drug information [Internet]. Uptodate; (C2020. Available from https://www-uptodatecom.ezproxy.sibdi.ucr.ac.cr/contents/lamotrigine-druginformation?search=lamotrigina\&source=panel_search_result\&selectedTitle=1 126\&usage_type=panel\&kp_ta b=drug_general\&display_rank=1

[83] Fischer A. Enfermedades por inmunodeficiencia primaria. In: Jameson JL, Fauci AS, Kasper DL, Hauser SL, Longo DL, Loscalzo J, eds. Harrison Principios de Medicina Interna. 20 th $\mathrm{ed.} \mathrm{New} \mathrm{York:} \mathrm{McGraw-Hill} \mathrm{Education;} 2018$.

[84] Ministerio de Salud Costa Rica. Lamotrigina. Casos raros de meningitis aséptica [Internet]. Costa Rica: Ministerio de Salud; (C)2010. Available from https://ministeriodesalud.go.cr/index.php/consulta-de-alertas-deseguridad/933-15-de-noviembre-2010-lamotrigina-casos-raros-de-meningitis-aseptica/file. 